\title{
Mental Health, Learning Behaviour and Perceived Fatigue Among University Students During the COVID-19 Outbreak: a Cross-sectional Multicentric Study in the UAE
}

Sultan Mosleh ( $\square$ smosleh@hct.ac.ae )

Higher collages of Technology

Raed Shudifat

Mutah University

Heyam Dalky

Higher collages of Technology

Mona Almalik

Higher collages of Technology

Malek Alnajar

Higher collages of Technology

\section{Research Article}

Keywords: COVID-19 outbreak, Psychological well-being, Fatigue level, Home confinement-related stress

Posted Date: August 17th, 2021

DOl: https://doi.org/10.21203/rs.3.rs-731975/v1

License: (c) (i) This work is licensed under a Creative Commons Attribution 4.0 International License.

Read Full License 


\section{Abstract}

\section{Background}

The rapid shift to online education due to COVID-19 quarantine challenged students' ability to accept pure online learning without negative consequences for their physical, emotional and mental health. Some educational institutions introduced new strategies to reduce the psychosocial burden associated with online learning during home confinement. Thus, The primary aims were to determine the consequences of COVID-19 for the psychological well-being and fatigue levels of higher education students and to explore the effects of a new academic assessment approach in reducing home confinement stress.

\section{Method}

A cross-sectional online survey was conducted among students of 7 disciplines in all 16 higher colleges of technology in the United Arab Emirates (UAE). The Mental Well-being and Learning Behaviours Scale and the modified Copenhagen Burnout Inventory were used to evaluate students' psychological wellbeing and fatigue levels. A t-test and ANOVA were performed to determine the differences in perceived psychological well-being and fatigue associated with students' characteristics. Second, multiple linear regression models performed to identify the independent predictors of fatigue level.

\section{Results}

One thousand four hundred students participated. The majority were female (78.5\%) and aged from 21 25 years $(58.1 \%)$. Around $14 \%$ of respondents were married with children. Nearly $40 \%$ were satisfied with the new assessment approach introduced during the COVID pandemic and $45.5 \%$ perceived it as having reduced their home confinement stress. The mean psychological distress score of 3.00 (SD \pm 0.71 ) indicates a moderate impact of COVID-19 on psychological well-being. Students' psychological distress was positively correlated with fatigue level $(0.256, p<0.001)$ and negatively correlated with the perceived impact of the new assessment approach on student lifestyle (-0.133), physical health (-0.149) and coping with stress (-0.125). Male students experienced significantly lower fatigue and better psychological wellbeing than female students.

\section{Conclusion}

The study reveals that new assessment approaches which emerged during home confinement reduced students' perception of stress and of impaired lifestyle. However, students still had a considerable burden of psychological distress, requiring further preventive measures to maintain their psychological well-being during future outbreak events. Educational institutions should consider additional strategies to improve students' preparedness for online teaching, which could help maintain their psychological well-being.

\section{Background}


Since the emergence of COVID-19 in Wuhan in December 2019, major extraordinary measures have been implemented globally to reduce transmission of the SARS-CoV-2 virus $(1,2)$. Despite these, within weeks the ensuing pandemic caused significant changes to the educational landscape worldwide. In the UAE, the first case of COVID-19 was identified on 29 January 2020. In response, the government has taken stringent steps to control the spread of the virus, including stay-home orders of two to three months duration (1, 3). On 3 March 2020, the UAE Ministry of Education announced that all schools, colleges and universities across the country would close for a month starting Sunday 8 March as part of efforts to contain the spread of the virus (4).

In response to the spread of COVID-19, higher education institutions (HEls) around the globe closed their physical campuses and moved rapidly from traditional face-to-face courses to remote or online courses $(5,6)$. According to the United Nations Educational, Scientific and Cultural Organization (7), the pandemic has interrupted the learning of more than one billion students in 129 countries worldwide. In the UAE, many HEls have been forced to make timely adjustments to ensure the provision of education and sustain students' academic progress.

Consequently, students are liable to have experienced stressors subsequent to the academic burden, lack of relaxation time and repeated examinations in a competitive environment $(8,9)$. The pandemic disrupted student life; normal classes were suspended and students could not participate in social activities, affecting their academic performance and aggravating stress levels $(1,10,11)$. Previous studies have found significantly high stress and anxiety levels among university and college students during the pandemic, negatively impacting their perception of online courses $(10,12,13)$.

Previous research has established that students' ability to use learning technology tools, lack of IT knowledge, lack of technical support during virtual classes and the inappropriateness of online course content were causes of students' distress and burden during home quarantine (10). Hasan and Bao (1) examined the effects on students' psychological distress of 'e-learning crack-up' during COVID-19 lockdown; their survey of 400 students identified perception of e-learning crack-up as a significant independent predictor of psychological distress.

The prevalence of emotional distress varies among recent studies but demonstrates that a considerable percentage of students risk psychological distress. For example, Li et al. (14) found that among 1210 students, $53.8 \%$ had severe to moderate psychological distress, with female students being associated with more significant emotional burnout. In a Spanish study, $34.19 \%$ of respondents showed moderate to extremely severe depression symptoms, $21.34 \%$ showed extremely severe anxiety symptoms and $28.14 \%$ exhibited moderate to severe stress symptoms subsequent to the COVID-19 pandemic (15). The literature also identifies various factors influencing students' mental health. A recent study among 7143 college students revealed that COVID-19-related factors such economic stressors, effects on daily life and academic delays were positively associated with the level of anxiety symptoms (10), while supportive family, living with parents and having a steady income were protective against high levels of anxiety. Moreover, the findings of Meo et al. (16) show that a sense of emotional detachment from family, friends 
and fellow students was significantly associated with emotional distress and had negatively impacted students' academic performance and total daily studying hours. Despite the extensive research conducted over the last year, however, no attention appears to have been paid to changes in assessment methods during the crisis, students' GPA before and after the outbreak and marital status. This study therefore explores the association of these factors with students' fatigue levels and psychological wellbeing.

\section{Significance of the study}

Before 2020, a major transition to online education was already underway. Over the past decades, online teaching had become a strategic objective for many HEls, including those in the UAE. Then, when the pandemic nature of the COVID-19 outbreak became evident in the spring of 2020, universities abruptly went online with very few days of planning (17). A growing body of literature recognises the importance of exploring the impact of the pandemic and the sudden shift to online learning on students' psychological well-being. To our knowledge, no studies within Arab culture and the Gulf countries have examined this impact. The study also aims to determine the association of students' characteristics with perceived psychological well-being and the fatigue associated with confinement due to the COVID-19 outbreak.

The Higher Colleges of Technology (HCT) is a federal educational institution comprising the largest student body in the UAE, with more than 20,000 students in 16 campuses across the country. Since March 2020, various strategies have been actioned to ensure a smooth transmission to online learning and teaching experience (3). One of strategies was to modify the academic assessment approach after extensive consultation with faculty and the endorsement of the HCT's Academic Council. Examples of changes to traditional exams include splitting them into multiple online quizzes and assignments; replacing them with projects or case studies, reducing the weight to $15 \%$ and distributing the remaining weight over other formative assessments; replacing them with e-portfolios; using questions with an increased level of cognitive complexity; and setting online, open-book practical exams (timed and scheduled during online class sessions).

This study examines three main hypotheses: 1) The abrupt transition to pure online learning increased students' psychological distress and fatigue; 2) The modified assessment strategy during home confinement moderated the effect on students' family lifestyles, physical health, mental health and stress; and 3) Students' perception of psychological well-being moderated fatigue levels and academic performance.

The results could assist colleges, administrators and policymakers in the UAE by providing a theoretical basis for assessing psychological well-being and identifying the appropriate actions to help students during future pandemics. It should also provide guidelines for policymakers on possible mechanisms to moderate the impacts of anxiety on students during such health crises. 


\section{Methods}

\section{Design and setting}

The study had a descriptive cross-sectional quantitative design. Data were collected at one point in time via an online survey sent to potential participants by email, to be completed at their convenience. The first email was sent on 30 August 2020 and up to three reminders were sent weekly to enhance the response rate. The target population was all 20,000 students on 16 HCT campuses across the UAE.

\section{Data collection}

Data were collected over one month. The survey, which took the participants about 10-14 minutes to complete, contained questions on demographics, academic performance, psychological well-being and fatigue. The first section elicited information about students' age, gender, marital status, academic level and GPA before and after the pandemic semester. Participants also reported their perceptions of the impact of learning from home on their daily family lifestyle, physical health, mental health and ability to cope with stress. These four items were assessed on a scale from 1 (very negatively) to 5 (very positively). A single-item measure was used to reduce the demand on participants and make it easier to complete the entire survey.

Psychological well-being was evaluated using the Mental Well-being and Learning Behaviors scale (16), a five-point Likert scale from 1 (strongly disagree) to 5 (strongly agree). This instrument had two parts, the first comprising twelve questions to assess psychological well-being and stressors resulting from COVID19 , with a higher score indicating a greater negative impact on students' well-being. The second part comprised eight items on learning behaviours during the COVID outbreak, with a higher score representing a more positive attitude to e-learning. In this study, the Cronbach's alpha values for psychological well-being and learning behaviours were $a=0.90$ and $a=0.87$ respectively.

Student fatigue level related to learning online from home subsequent to the COVID-19 pandemic was evaluated by a modified version of the Copenhagen Burnout Inventory (18). The modified scale comprised 16 items in three subscales, measuring personal burnout attributed by the participant to factors unrelated to work ( 5 items), to working online ( 5 items) and to learning from home (3 items). All items were scored on a four-point Likert scale. The internal consistency of the three subscales was $a=$ $0.87, a=0.884$ and $a=0.83$ respectively.

The instrument was piloted among 25 students to determine whether the items were clear and concise, before being administered to the full sample.

\section{Data analysis}

The data were analysed quantitatively. All collected data were organized and summarized by descriptive statistics (measures of central tendency, dispersion and percentages) and the chi-square test was applied to determine how some demographic variables varied with the students' knowledge and health outcomes. 
Mean and standard deviation were reported to represent the average score for each scale item. In all statistical tests, two-tailed tests of significance and confidence intervals were based on the $p<0.05$ level. First, t-test and ANOVA were performed to determine the differences in perceived psychological well-being and fatigue associated with students' characteristics. Second, to identify the independent predictors of fatigue level, significant variables that emerged from univariate analysis were used to build multiple linear regression models. The software used for data analysis was SPSS version 23 (19).

\section{Ethical considerations}

This study was conducted with the approval of the Research and Ethical Committee of the Higher Colleges of Technology. Students signed an informed consent and informed that their participation was voluntary, and that they could withdraw from the study at any time. Data collection process was carried out in accordance with relevant guidelines and regulations.

\section{Results}

One thousand four hundred students participated in the study. Most were female (78.5\%) and aged $21-$ 25 years $(58.1 \%)$, while around $14 \%$ were married with children (Table 1 ). 
Table 1

Participants' demographics ( $\mathrm{N}=1431)$

\begin{tabular}{|c|c|c|}
\hline Variable & & n (\%) \\
\hline \multirow[t]{7}{*}{ Faculty } & Business & $366(25.6)$ \\
\hline & Computer Information Science & $301(21.0)$ \\
\hline & Education & $57(4.0)$ \\
\hline & Engineering & $347(24.2)$ \\
\hline & Health Sciences & $278(19.4)$ \\
\hline & Military and Security & $6(0.4)$ \\
\hline & General Academic Require-ments Division & $76(5.3)$ \\
\hline \multirow[t]{4}{*}{ Age in years } & Under 20 & $532(37.2)$ \\
\hline & $21-25$ & $831(58.1)$ \\
\hline & $26-30$ & $49(3.4)$ \\
\hline & More than 30 & $19(1.3)$ \\
\hline \multirow[t]{2}{*}{ Gender } & Male & $308(21.5)$ \\
\hline & Female & $1123(78.5)$ \\
\hline \multirow[t]{4}{*}{ Marital status } & Married & $120(8.4)$ \\
\hline & Single & $1300(90.8)$ \\
\hline & Divorced & $8(.6)$ \\
\hline & Widowed & $3(.2)$ \\
\hline \multirow{5}{*}{$\begin{array}{l}\text { Number of } \\
\text { children }\end{array}$} & None & $1352(94.5)$ \\
\hline & 1 & $45(3.1)$ \\
\hline & 2 & $16(1.1)$ \\
\hline & 3 & $9(.6)$ \\
\hline & 4 & $3(.2)$ \\
\hline \multirow[t]{3}{*}{ Work status } & Employed full time & $82(5.7)$ \\
\hline & Employed part time & $40(2.8)$ \\
\hline & Unemployed & 1309 (91.5) \\
\hline
\end{tabular}




\begin{tabular}{|lll|}
\hline Variable & & $\mathbf{n}(\%)$ \\
\hline Student level & Semester two & $316(22.1)$ \\
& Semester three & $250(17.5)$ \\
& Semester four & $159(11.1)$ \\
& Semester five & $147(10.3)$ \\
& Semester six & $175(12.2)$ \\
& Semester seven & $182(12.7)$ \\
& Semester eight & $202(14.1)$ \\
\hline
\end{tabular}

\subsection{Impact of the COVID outbreak on academic performance}

During COVID-19 quarantine, major coursework assessments were split into short quizzes and open-book exams. Almost $40 \%$ of participants reported being satisfied with the changes in assessment delivery method during home confinement and $45.5 \%$ perceived it as having reduced their stress. Three quarters of participants $(76 \%)$ reported an improvement in their GPA during the pandemic semester and a similar percentage believed that online assessment had succeeded in reducing their stress levels. Projects and open-book exams (instead of the final written exam) were the assessment methods perceived as having contributed most to GPA improvement and stress reduction during COVID-19 quarantine (Table 2). 
Table 2

Impact of online teaching and modified assessment method on academic performance

\begin{tabular}{|c|c|c|}
\hline Variables & & $\mathrm{n}(\%)$ \\
\hline \multirow[t]{2}{*}{ Has your GPA improved at the end of Spring 2020 semester? } & Yes & $\begin{array}{l}1090 \\
(76.2)\end{array}$ \\
\hline & No & $341(23.8)$ \\
\hline \multirow[t]{2}{*}{$\begin{array}{l}\text { Did the modified assessment reduce your stress associated } \\
\text { with home confinement? }\end{array}$} & Yes & $\begin{array}{l}1082 \\
(75.6)\end{array}$ \\
\hline & No & $349(24.4)$ \\
\hline \multirow[t]{7}{*}{ The most successful type of online assessment } & Final exam & $628(43.9)$ \\
\hline & Case study & $470(32.8)$ \\
\hline & Project & $715(50)$ \\
\hline & Presentation & $647(45.2)$ \\
\hline & Test/quiz & $693(48.4)$ \\
\hline & Written assignment & $487(34)$ \\
\hline & Open book exam & $650(45.4)$ \\
\hline \multirow[t]{2}{*}{ Was the final exam replaced? } & Yes & $369(25.8)$ \\
\hline & No & $\begin{array}{l}1062 \\
(74.2)\end{array}$ \\
\hline \multirow{7}{*}{$\begin{array}{l}\text { Which of the following were included in your course to replace } \\
\text { an online Spring } 2020 \text { final exam? }\end{array}$} & Exam & $139(9.7)$ \\
\hline & Case Study & $242(16.9)$ \\
\hline & Project & $184(12.9)$ \\
\hline & Presentation & $126(8.8)$ \\
\hline & Test/quiz & $108(7.5)$ \\
\hline & Written assignment & $145(10.1)$ \\
\hline & $\begin{array}{l}\text { Open book exam } \\
\text { (non-FWA) }\end{array}$ & $13(.9)$ \\
\hline
\end{tabular}


The improvement in your GPA was due to:

$\begin{array}{ll}\text { Case Study } & 428(29.9) \\ \text { Project } & 732(51.3) \\ \text { Presentation } & 552(38.6) \\ \text { Test/quiz } & 555(38.8) \\ \begin{array}{l}\text { Written assignment } \\ \begin{array}{l}\text { Open book exam } \\ \text { (non-FWA) }\end{array}\end{array} & 420(29.6) \\ & 574(40.1)\end{array}$

\section{Impact of new assessment approach on student stress level}

Students reported diverse perceptions of the impact of modified assessment during the COVID-19 pandemic. A fifth (22\%) of students reported a negative effect on family lifestyle, while more than half (53\%) said this impact was positive. Over a quarter (27.8\%) reported a negative effect on physical health, while almost as many $(27.1 \%)$ perceived negative mental health effects. As to stress, $28.8 \%$ of students felt that online assessment had increased their stress levels, whereas $45.5 \%$ felt that the modified assessment had reduced their stress.

Table 3

Impact of new assessment models on students ( $\mathrm{N}=1431)$

\begin{tabular}{|lllllll|}
\hline Domain & $\begin{array}{l}\text { Very } \\
\text { negatively }\end{array}$ & Negatively & No effect & Positively & $\begin{array}{l}\text { Very } \\
\text { positively }\end{array}$ & M(SD) \\
\hline $\begin{array}{l}\text { Family } \\
\text { lifestyle }\end{array}$ & $113(7.9)$ & $211(14.7)$ & $\begin{array}{l}353 \\
(24.7)\end{array}$ & $\begin{array}{l}328 \\
(22.9)\end{array}$ & $426(29.8)$ & 3.52 \\
$\begin{array}{l}\text { Physical } \\
\text { health }\end{array}$ & $144(10.1)$ & $254(17.7)$ & $358(25)$ & $\begin{array}{l}287 \\
(20.1)\end{array}$ & $388(27.1)$ & 3.36 \\
\hline Mental health & $146(10.2)$ & $242(16.9)$ & $\begin{array}{l}345 \\
(24.1)\end{array}$ & $\begin{array}{l}307 \\
(21.5)\end{array}$ & $391(27.3)$ & 3.39 \\
\hline Stress levels & $180(12.6)$ & $232(16.2)$ & $\begin{array}{l}369 \\
(25.8)\end{array}$ & $\begin{array}{l}292 \\
(20.4)\end{array}$ & $358(25)$ & $\begin{array}{l}3.29 \\
(1.3)\end{array}$ \\
\hline
\end{tabular}

\section{Student fatigue during e-learning}

The average total fatigue score was $35.69 / 64(S D=13.9)$ with a range of 16 to 64 , indicating moderate fatigue. On the personal, online learning and learning from home burnout subscales respectively, the 
average scores were 2.27 ( $S D=0.823), 2.61(S D=1.16)$ and $2.246(S D=1.00)$. Results on all subscales indicate low fatigue levels associated with e-learning. However, a significant percentage of students reported always having fatigue more than five days per week.

\section{Students' psychological well-being during the COVID pandemic and quarantine}

Participants' mean score on psychological well-being was 3.0/5 $(\mathrm{SD}=.71)$, indicating a moderate impact. The mean score on the mental health subscale was $3.00(S D=.87)$ and approximately a third of students agreed that they were always thinking about being infected with the virus, with a mean of 3.07. Thirtyseven percent of students perceived themselves as depressed, while $31.1 \%$ agreed that they felt detached from social life, were anxious and suffered from insomnia, with a mean of 2.99 .

On the learning behaviour subscale, the mean score was $3.01(S D=.68)$, indicating a moderate impact of COVID-19 on learning behaviour. Lack of motivation was reported by $22.6 \%$ of students, while $18 \%$ said they suffered from poor concentration and $23.3 \%$ had difficulty remembering recent information. Almost $40 \%$ reported an increase in time spent studying, while $25 \%$ stated that this time had decreased.

Univariate coefficients for the association between the main study outcomes are presented in Table 4. A significant positive relationship emerges between fatigue and psychological distress, indicating that students who perceived a higher level of psychological distress also perceived higher fatigue levels. In addition, a significantly higher impact on psychological well-being (mental health and learning behaviour) was observed among students who reported a low negative impact of the new assessment approach on their lifestyle, physical health and coping with stress. 
Table 4

Correlation coefficient between psychological well-being, fatigue and stress

\begin{tabular}{|c|c|c|c|c|c|}
\hline & Fatigue & $\begin{array}{l}\text { Psychological } \\
\text { distress }\end{array}$ & $\begin{array}{l}\text { Satisfied } \\
\text { with new } \\
\text { assessments }\end{array}$ & $\begin{array}{l}\text { Impact of } \\
\text { new } \\
\text { assessment } \\
\text { on family } \\
\text { lifestyle }\end{array}$ & $\begin{array}{l}\text { Impact of } \\
\text { new } \\
\text { assessment } \\
\text { on physical } \\
\text { health }\end{array}$ \\
\hline Psychological distress & $.254^{\star \star}$ & & & & \\
\hline $\begin{array}{l}\text { Satisfaction with new } \\
\text { assessment approach }\end{array}$ & $-.435^{\star \star}$ & $-.060^{*}$ & & & \\
\hline $\begin{array}{l}\text { Impact of new } \\
\text { assessment on Family } \\
\text { lifestyle }\end{array}$ & $-.552^{\star \star}$ & $-.133^{* *}$ & $.459^{\star \star}$ & & \\
\hline $\begin{array}{l}\text { Impact of new } \\
\text { assessment on } \\
\text { Physical health }\end{array}$ & $-.564^{\star \star}$ & $-.149^{* *}$ & $.443^{* \star}$ & $.766^{* *}$ & \\
\hline $\begin{array}{l}\text { Impact of new } \\
\text { assessment on ability } \\
\text { to cope with stress }\end{array}$ & $-.574^{\star \star}$ & $-.125^{\star \star}$ & $.451^{\star \star}$ & $.723^{* \star}$ & $.723^{\star \star}$ \\
\hline$\star * p<0.01, * p<0.05$ & & & & & \\
\hline
\end{tabular}

\section{Differences based on students' demographical characteristics}

Various sociodemographic variables showed a significant association with study outcomes (Table 5). Male students experienced significantly lower fatigue and better psychological well-being than females. Health science students experienced significantly less fatigue than those on other programmes, except for business students, and had better psychological well-being (but not statistically significantly). 
Table 5

Differences of attitudes, fatigue, and psychological well-being means scores based on students' demographics $(\mathrm{N}=1431)$

\begin{tabular}{|c|c|c|c|c|c|c|}
\hline \multirow[t]{2}{*}{ Variable } & \multicolumn{3}{|c|}{$\begin{array}{l}\text { Fatigue } \\
M(S D)\end{array}$} & \multicolumn{3}{|c|}{$\begin{array}{l}\text { Psychological } \\
\text { wellbeing } \\
\text { M (SD) }\end{array}$} \\
\hline & f & df & $p^{*}$ & $f$ & df & $p^{*}$ \\
\hline Gender & -5.6 & 1429 & $<.001$ & -1.9 & 1429 & .054 \\
\hline Male & \multicolumn{3}{|c|}{$1.98(.86)$} & \multicolumn{3}{|c|}{$2.94(.75)$} \\
\hline Female & \multicolumn{3}{|c|}{$2.29(.85)$} & \multicolumn{3}{|c|}{$3.02(.7)$} \\
\hline Faculty & 2.9 & 6 & .008 & 1.2 & 6 & .277 \\
\hline Business & \multicolumn{3}{|c|}{$2.11(.87)$} & \multicolumn{3}{|c|}{$3.01(.77)$} \\
\hline Computer Information Science \& Applied Media & \multicolumn{3}{|c|}{$2.25(.89)$} & \multicolumn{3}{|c|}{$3(.74)$} \\
\hline Education & \multicolumn{3}{|c|}{$2.34(.76)$} & \multicolumn{3}{|c|}{$3.11(.68)$} \\
\hline Engineering Technology and Science & \multicolumn{3}{|c|}{$2.67(.86)$} & \multicolumn{3}{|c|}{$3(.66)$} \\
\hline Health Sciences & \multicolumn{3}{|c|}{$2.38(.83)$} & \multicolumn{3}{|c|}{$3.01(.65)$} \\
\hline Military and Security & \multicolumn{3}{|c|}{$2.2(.68)$} & \multicolumn{3}{|c|}{$2.28(.89)$} \\
\hline General Academic Requirements Division & \multicolumn{3}{|c|}{$2.29(.89)$} & \multicolumn{3}{|c|}{$2.97(.71)$} \\
\hline Age in years & 6.7 & 3 & $<.001$ & .98 & 3 & .41 \\
\hline Less than 20 & \multicolumn{3}{|c|}{$2.31(.83)$} & \multicolumn{3}{|c|}{$3(.74)$} \\
\hline $21-25$ & \multicolumn{3}{|c|}{$2.2(.88)$} & \multicolumn{3}{|c|}{$3(.69)$} \\
\hline $26-30$ & \multicolumn{3}{|c|}{$1.78(.72)$} & \multicolumn{3}{|c|}{$2.8(.79)$} \\
\hline More than 30 & \multicolumn{3}{|c|}{$2(.81)$} & \multicolumn{3}{|c|}{$3.22(.53)$} \\
\hline Marital status & 3.31 & 3 & .019 & 3.1 & 3 & .024 \\
\hline Married & \multicolumn{3}{|c|}{$2(.82)$} & \multicolumn{3}{|c|}{$2.9(.7)$} \\
\hline Single & \multicolumn{3}{|c|}{$2.25(.87)$} & \multicolumn{3}{|c|}{$3(.71)$} \\
\hline Divorced & \multicolumn{3}{|c|}{$2.17(.81)$} & 2.73 & .42) & \\
\hline Widowed & $1.6($. & & & $2(.4$ & & \\
\hline Number of children & 4.05 & 4 & .003 & .64 & 4 & .63 \\
\hline
\end{tabular}

None 


\begin{tabular}{|c|c|c|c|c|}
\hline $\begin{array}{l}\text { Zariable } \\
3 \\
4\end{array}$ & \multicolumn{2}{|l|}{$M(S D)$} & \multicolumn{2}{|c|}{$\begin{array}{l}\text { Psychological } \\
\text { wellbeing } \\
\text { M (SD) }\end{array}$} \\
\hline \multirow{5}{*}{4} & \multicolumn{2}{|l|}{$2.24(.87)$} & \multicolumn{2}{|l|}{$3(.71)$} \\
\hline & \multicolumn{2}{|l|}{$1.95(.81)$} & \multicolumn{2}{|l|}{$2.8(.69)$} \\
\hline & \multicolumn{2}{|l|}{$2(.68)$} & \multicolumn{2}{|l|}{$2.9(.61)$} \\
\hline & \multicolumn{2}{|l|}{$1.39(.39)$} & \multicolumn{2}{|l|}{$2.96(.95)$} \\
\hline & \multicolumn{2}{|l|}{$1.56(.4)$} & \multicolumn{2}{|l|}{$3(.39)$} \\
\hline Working status & 3.312 & .037 & .392 & .67 \\
\hline Employed full time & \multicolumn{2}{|l|}{$2(.82)$} & \multicolumn{2}{|l|}{$3.07(.89)$} \\
\hline Employed part time & \multicolumn{2}{|l|}{$2.3(.83)$} & \multicolumn{2}{|l|}{$2.98(.67)$} \\
\hline Unemployed & \multicolumn{2}{|l|}{$2.24(.87)$} & \multicolumn{2}{|l|}{$3(.7)$} \\
\hline Student level & 1.226 & .29 & .836 & .54 \\
\hline Semester two & \multicolumn{2}{|l|}{$2.3(.84)$} & \multicolumn{2}{|l|}{$3(.8)$} \\
\hline Semester three & \multicolumn{2}{|l|}{$2.28(.84)$} & \multicolumn{2}{|l|}{$2.97(.71)$} \\
\hline Semester four & \multicolumn{2}{|l|}{$2.24(.86)$} & \multicolumn{2}{|l|}{$3.1(.67)$} \\
\hline Semester five & \multicolumn{2}{|l|}{$2.24(.9)$} & \multicolumn{2}{|l|}{$3(.75)$} \\
\hline Semester six & \multicolumn{2}{|l|}{$2.18(.95)$} & \multicolumn{2}{|l|}{$2.99(.69)$} \\
\hline Semester seven & \multicolumn{2}{|l|}{$2.15(.9)$} & \multicolumn{2}{|l|}{$2.98(.65)$} \\
\hline Semester eight & \multicolumn{2}{|l|}{$2.13(.79)$} & \multicolumn{2}{|l|}{$2.96(.63)$} \\
\hline Current GPA & 3.796 & .001 & 3.06 & .006 \\
\hline Not calculated (semester 2 students) & \multicolumn{2}{|l|}{$2.37(.77)$} & $3.34(.78)$ & \\
\hline Below 1 & $2.3(.84)$ & & $3.34(1.1)$ & \\
\hline 1 to 1.9 & $2.12(.85)$ & & $3.1(.8)$ & \\
\hline 2 to 2.9 & $2.33(.9)$ & & $2.98(.7)$ & \\
\hline Above 3 & $2.42(.8)$ & & $2.98(.69)$ & \\
\hline Previous GPA & 5.096 & $<.001$ & 1.16 & .37 \\
\hline
\end{tabular}

Not calculated (semester 2 students)

Below 1

1 to 1.9 


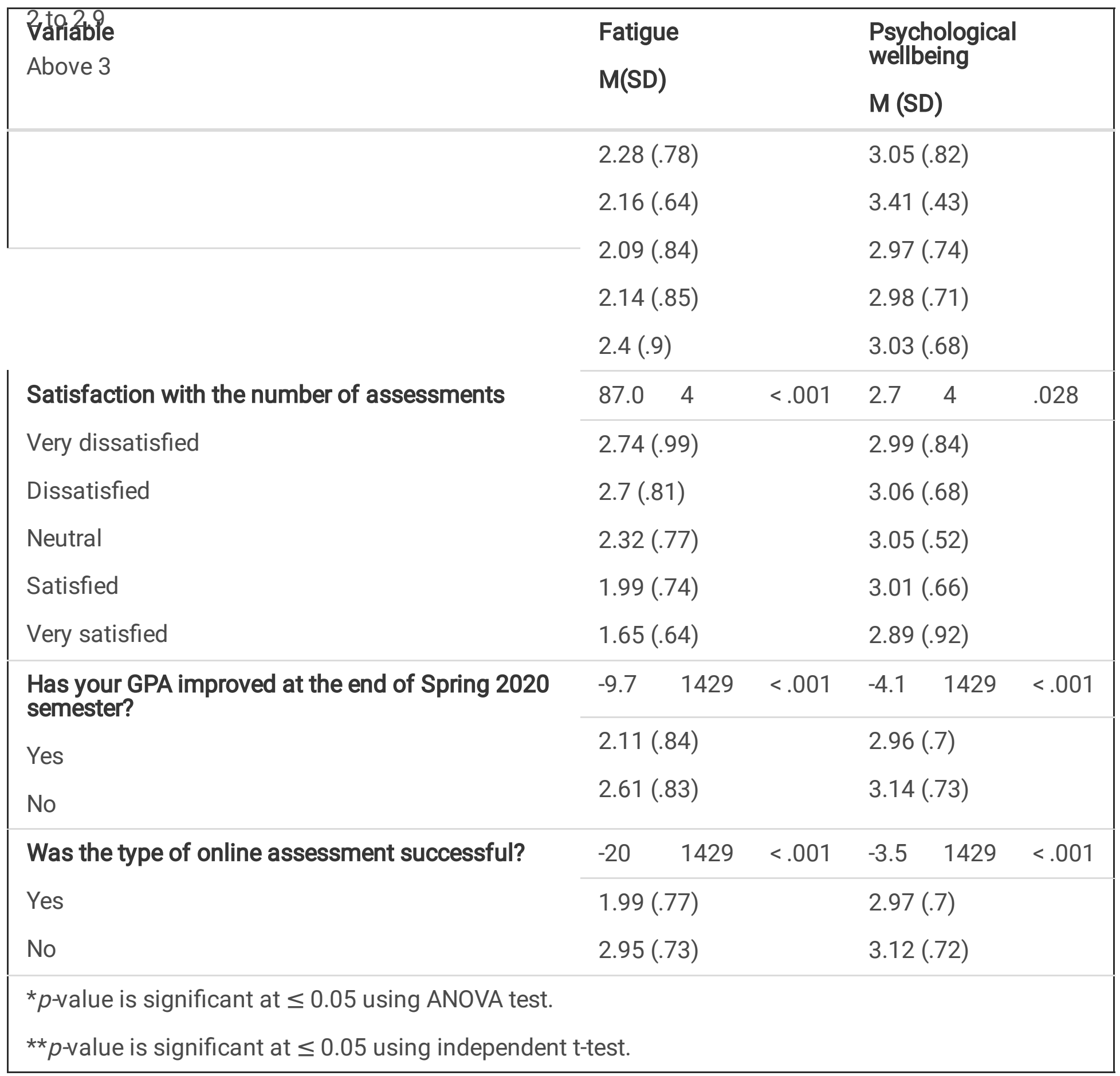

\section{Discussion}

The COVID-19 pandemic has caused an unpredictable and unprecedented wave of closures of academic facilities, affecting millions of HEl students worldwide. Many academic institutions have been forced to take difficult decisions and implement modifications to their teaching and learning activities in order to continue delivering courses while avoiding the risk of virus transmission associated with students attending campuses.

The present study documents perceptions of student-centred active learning delivered through full distance learning during the pandemic period among a group of undergraduate students enrolled in 
various programmes at HCT campuses across the UAE. The HCT was already providing many online learning methods and tools for both teachers and students, but most of these were not fully utilized before the COVID-19 pandemic. During the pandemic, full distance learning was adopted, whereby online group discussions and new online assessments were carried out synchronously through the online communication platform known as BBL-Ultra. This study is the first to report on students' perceptions of the effectiveness of the fully online learning methods and their learning satisfaction during the COVIDrelated restrictions.

\section{Student fatigue during e-learning}

Participating students reported moderate fatigue levels when engaged in e-learning during the COVID-19 quarantine period. All subscales indicated low fatigue levels associated with e-learning. However, a significant percentage of students stated that they always felt fatigued more than five days per week. Possible reasons for these results, which are congruent with previous studies $(10,14,20)$, are the cumulative psychological and physiological burden experienced due to the unprecedented experiences associated with COVID-19 in the personal, social and academic domains. Results for the different items of the three scales indicate that students perceived the e-learning process to engender a burden that could negatively impact their psychological status and academic achievements. Future studies should investigate in more depth factors escalating these burdens and seek solutions to minimize or prevent fatigue.

\section{Students' psychological well-being during the COVID pandemic and quarantine}

Participants in this study reported poor psychological well-being due to quarantine. This result was expected, as students were required to fully accept unpredictable changes and adapt to them immediately. Similar findings are reported by Cao and colleagues (1), who state that college students in China reported moderate to high anxiety levels and suffered many psychological effects of COVID-19 and the subsequent quarantine. One explanation for this might be the extended time spent working alone on computer screens, accompanied by the anxiety of being quarantined, adapting to an unprecedented situation and absorbing news about numbers of confirmed COVID-19 cases or resultant deaths.

Students taking part in this study were preoccupied with the fear of COVID infection, resulting in feelings of depression or anxiety which could be related to their reports of insomnia and lack of motivation. Similar results have recently been reported, where students in various programmes and at several academic levels reported moderate to severe levels of anxiety or mental health concerns $(9,19,21)$. Further, various factors were reported as stressors contributing to feelings of anxiety or depression during the pandemic. Although exploring the factors/stressors contributing to anxiety goes beyond the purpose of this study, it is worth noting that students pursuing their studies online while being quarantined at home are likely to face many risks that would negatively impact their psychological status and mental well-being. Possible stressors are having a family member with a confirmed COVID-19 infection at home, 
changes imposed on their daily routines and fear of academic delays. Indeed, it is strongly recommended that educational institutions and authorities should provide students with continuous support, ensuring the availability of the necessary emotional support mechanisms and counselling services, which should be available and accessible as per each institution's guidelines.

This study has revealed a significant psychological effect of the COVID-19 pandemic on the teaching and learning of HCT students. While the crisis has been stressful for students, they are hoping, in common with other community members, that it will eventually end, that restrictions will be eased and that their lives will return, albeit gradually, to a pre-COVID normality. Therefore, in addition to sustaining students' emotional and psychological well-being, offering stress counselling and applying the hybrid model of teaching which the HCT has announced, it is essential to continue to provide a reliable educational environment and to prepare a safe future for students. HCT students are familiar with e-learning but did not experience fully online delivery until the restrictive quarantine measures came into force. Any class of students will have diverse learning styles and it will thus be very challenging for the teacher to adapt and accommodate e-learning methods and tools to best meet their collective needs.

\section{Conclusion}

The study reveals that new assessment approaches which emerged during home confinement reduced students' perception of stress and of impaired lifestyle. However, students still had a considerable burden of psychological distress, requiring further preventive measures to maintain their psychological well-being during future outbreak events. Educational institutions should consider additional strategies to improve students' preparedness for online teaching, which could help maintain their psychological well-being.

One of the main limitations of this study is its cross-sectional design; while this suited the present purpose, a future longitudinal study would be highly recommended to determine the long-term impacts on students' health of the COVID-19 crisis. On the other hand, the large sample size among multiple colleges involved in the study is considered a strong point, upholding the generalizability of the findings and enabling the drawing of solid conclusions about the current situation in UAE universities on which to ground a possible national crisis strategy.

Fatigue levels were measured using a version of the Copenhagen Burnout Inventory, modified to fit the purpose of investigating online learning during COVID-19 quarantine. Although the three subscales as modified were found to have good internal consistency, further research could be conducted to confirm the internal validity of the scale. Finally, a further study could employ a more complex analytical approach to determine the confounding variables for students' psychological well-being and the mediating effect of fatigue level.

\section{Declarations}

\section{Ethics approval and consent to participate}


This study was conducted with the approval of the Research and Ethical Committee of the Higher Colleges of Technology. Students were informed that their participation was voluntary and that they could withdraw from the study at any time.

\section{Availability of data and materials}

The datasets used and/or analysed during the current study are available from the corresponding author on reasonable request.

\section{Funding}

No fund to declare

\section{Competing interesting}

The authors declare that they have no actual or potential conflicts of interests.

\section{Authors' contributions}

S.M designed and directed the project, S.M and M.K performed the analysis. MM interpret data and wrote the results. S.M aided in interpreting the results and work on manuscript. R.M and H.F draft the introduction and discussion sections. S.M wrote the paper with input from all authors. All authors read and approved the final manuscript.

\section{Acknowledgments}

We would like to thank HCT student who participated in the study and completed the questionnaires during the outbreak period. Also, we appreciate the IT staff for developing the online version of the questionnaires.

\section{References}

1. Hasan N, Bao Y. Impact of "e-Learning crack-up" perception on psychological distress among college students during COVID-19 pandemic: A mediating role of "fear of academic year loss." Child Youth Serv Rev. 2020;118. https://doi.org/10.1016/j.childyouth.2020.105355

2. Mahdy MAA. The Impact of COVID-19 Pandemic on the Academic Performance of Veterinary Medical Students. Front Vet Sci. 2020;7. https://doi.org/10.3389/fvets.2020.594261

3. Alshamsi A, Zahavich A, El-Farra S. Why Graded Assessment for Undergraduates During the COVID19 Lockdown? An Experience Introspection. IAFOR J Educ. 2021;9(2).

4. Masoud N, Bohra OP. CHALLENGES AND OPPORTUNITIES OF DISTANCE LEARNING DURING COVID19 IN UAE. Acad Account Financ Stud J. 2020;24(1).

5. Sundarasen S, Chinna K, Kamaludin K, Nurunnabi M, Baloch GM, Khoshaim HB, et al. Psychological impact of covid-19 and lockdown among university students in malaysia: Implications and policy 
recommendations. Int J Environ Res Public Health. 2020;17(17).

https://doi.org/10.3390/ijerph17176206

6. Elzainy A, El Sadik A, Al Abdulmonem W. Experience of e-learning and online assessment during the COVID-19 pandemic at the College of Medicine, Qassim University. J Taibah Univ Med Sci. 2020;15(6).

7. UNESCO. Covid-19 Impact on Education Data: COVID-19 Education Disruption and Response. United Nations Educational, Scientific and Cultural Organization. 2020.

8. Amir LR, Tanti I, Maharani DA, Wimardhani YS, Julia V, Sulijaya B, et al. Student perspective of classroom and distance learning during COVID-19 pandemic in the undergraduate dental study program Universitas Indonesia. BMC Med Educ. 2020;20(1). https://doi.org/10.1186/s12909-02002312-0

9. Copeland WE, McGinnis E, Bai Y, Adams Z, Nardone H, Devadanam V, et al. Impact of COVID-19 Pandemic on College Student Mental Health and Wellness. J Am Acad Child Adolesc Psychiatry. 2021;60(1). https://doi.org/10.1016/j.jaac.2020.08.466

10. Cao W, Fang Z, Hou G, Han M, Xu X, Dong J, et al. The psychological impact of the COVID-19 epidemic on college students in China. Psychiatry Res. 2020;287.

https://doi.org/10.1016/j.psychres.2020.112934

11. George G, Thomas MR. Quarantined effects and strategies of college students - COVID-19. Asian Educ Dev Stud. 2020. https://doi.org/10.1108/AEDS-04-2020-0054

12. Alam MK, Ali F Bin, Banik R, Yasmin S, Salma N. Assessing the mental health condition of homeconfined university level students of Bangladesh due to the COVID-19 pandemic. Journal of Public Health (Germany). 2021. https://doi.org/10.1007/s10389-021-01542-w

13. Husky MM, Kovess-Masfety V, Swendsen JD. Stress and anxiety among university students in France during Covid-19 mandatory confinement. Compr Psychiatry. 2020;102.

14. Li X, Wu H, Meng F, Li L, Wang Y, Zhou M. Relations of COVID-19-Related Stressors and Social Support With Chinese College Students' Psychological Response During the COVID-19 Pandemic. Front Psychiatry. 2020;11.

15. Odriozola-González P, Planchuelo-Gómez Á, Irurtia MJ, de Luis-García R. Psychological effects of the COVID-19 outbreak and lockdown among students and workers of a Spanish university. Psychiatry Res. 2020;290.

16. Meo SA, Abukhalaf DAA, Alomar AA, Sattar K, Klonoff DC. COVID-19 Pandemic: Impact of Quarantine on Medical Students' Mental Wellbeing and Learning Behaviors. Pakistan J Med Sci. 2020 May 11;36(COVID19-S4). https://doi.org/10.12669/pjms.36.COVID19-S4.2809

17. Sahu P. Closure of Universities Due to Coronavirus Disease 2019 (COVID-19): Impact on Education and Mental Health of Students and Academic Staff. Cureus. 2020; 12(4), e7541. https://doi.org/10.7759/cureu s.7541

18. Kristensen TS, Borritz M, Villadsen E, Christensen KB. The Copenhagen Burnout Inventory: A new tool for the assessment of burnout. Work Stress. 2005 Jul;19(3):192-207. 
https://doi.org/10.1080/02678370500297720

19. Khawar MB, Abbasi MH, Hussain S, Riaz M, Rafiq M, Mehmood R, et al. Psychological impacts of COVID-19 and satisfaction from online classes: disturbance in daily routine and prevalence of depression, stress, and anxiety among students of Pakistan. Heliyon. 2021;7(5). https://doi.org/10.1016/j.heliyon.2021.e07030

20. Tang W, Hu T, Hu B, Jin C, Wang G, Xie C, et al. Prevalence and correlates of PTSD and depressive symptoms one month after the outbreak of the COVID-19 epidemic in a sample of home-quarantined Chinese university students. J Affect Disord. 2020;274. https://doi.org/10.1016/j.jad.2020.05.009

21. Brett Williams, King C, Shannon B, Gosling C. Impact of COVID-19 on paramedicine students: A mixed methods study. Int Emerg Nurs. 2021;56. 